\title{
ANALISIS PENYAJIAN LAPORAN KEUANGAN BERDASARKAN PENERAPAN STANDAR AKUNTANSI KEUANGAN ENTITAS TANPA AKUNTABILITAS PUBLIK PADA PT. FORTUNA INTI ALAM
}

\author{
Marddyanto Dwi Saputra ${ }^{1}$, Jullie J. Sondakh ${ }^{2}$, Treesje Runtu ${ }^{3}$ \\ ${ }^{1}$ Jurusan Akuntansi, Fakultas Ekonomi dan Bisnis, Universitas Sam Ratulangi, Jl. Kampus Unsrat, Manado, \\ 95115, Indonesia \\ ${ }^{2}$ Jurusan Akuntansi, Fakultas Ekonomi dan Bisnis, Universitas Sam Ratulangi, Jl. Kampus Unsrat, Manado, \\ 95115, Indonesia \\ ${ }^{3}$ Jurusan Akuntansi, Fakultas Ekonomi dan Bisnis, Universitas Sam Ratulangi, Jl. Kampus Unsrat, Manado, \\ 95115, Indonesia \\ E-mail : mardyanputra@gmail.com
}

\begin{abstract}
The financial statements in principle are the result of the accounting process used to communicate the financial situation to internal and external parties that are aimed at decision making. The importance of the financial statements, then the financial statement should be prepared carefully and without errors. Financial Accounting Standards generally are not in accordance with entities whose accountability is not as significant. Therefore, the Institute of Indonesia Chartered Accountants (IAI) has issued Financial Accounting Standards Entity Without Public Accountability (SAK ETAP) intended for entities that do not have significant public accountability and publish financial statements for general purposes for external users. This study aims to analyze the implementation of ETAP in the presentation of PT. Fortuna Inti Alam's financial statement. The method used in this study is comparative descriptive analysis. Results of this research is based on the financial statements of 2016 show that PT. Fortuna Inti Alam has implemented ETAP but it is not fully complete yet. The Company has not presented Statement of Owner's Equity, Cash Flow Statement, and Notes to Financial Statements. This research suggests that companies can prepare components of other financial statements in accordance with applicable standards.
\end{abstract}

Keywords : Financial Statements, SAK ETAP.

\section{PENDAHULUAN}

Untuk menilai kelayakan suatu usaha, sangatlah perlu untuk mengetahui kondisi keuangan perusahaan tersebut. Sementara itu kondisi keuangan akan dapat diketahui dari laporan keuangan perusahaan yang bersangkutan, yang terdiri atas Neraca dan Laporan Perhitungan Laba Rugi serta laporan keuangan lainnya. Melalui analisis terhadap pos-pos neraca akan dapat diketahui tentang posisi keuangan perusahaan tersebut, sedangkan analisis terhadap laporan laba rugi akan memberikan gambaran tentang prestasi atau perkembangan perusahaan yang bersangkutan. (Jumingan, 2014:188)

Laporan keuangan pada prinsipnya merupakan hasil dari proses akuntansi, yang dipergunakan untuk mengkomunikasikan keadaan keuangan atau prestasi manajemen kepada pihak internal maupun eksternal yang bertujuan untuk pengambilan keputusan. Laporan keuangan menunjukkan kinerja keuangan perusahaan pada tahun sekarang guna sebagai bahan evaluasi kinerja keuangan perusahaan tahun berikutnya. (Senoaji, 2014) 
Namum demikian, kiranya perlu dipahami beberapa keterbatasan laporan keuangan, diantaranya apabila kita membandingkan dua laporan keuangan perusahaan dapat terjadi hasil yang kita peroleh tidak memberikan kesimpulan yang benar, hal ini disebabkan karena metode yang berbeda. Seorang akuntan diharapkan mampu untuk mengorganisir seluruh data akuntansi sehingga menghasilkan laporan keuangan, dan bahkan harus dapat menginterpretasikan serta menganalisis laporan keuangan yang dibuatnya.

Menganalisis laporan keuangan berarti menggali lebih banyak informasi yang dikandung suatu laporan keuangan. Jika informasi ini disajikan dengan benar, informasi tersebut sangat berguna bagi siapa saja untuk mengambil keputusan tentang perusahaan yang dilaporkan tersebut. Laporan keuangan biasanya diperoleh dari proses berjalannya sistem akuntansi. Untuk tidak salah dalam memakai informasi laporan akuntansi ini maka perlu diketahui secara benar pengertian dari proses akuntansi. (Harahap, 2013)

Melihat pentingnya laporan keuangan dalam menilai kesehatan perusahaan dan pengambilan keputusan, maka laporan keuangan harus disusun secara cermat dan terbebas dari bias. laporan keuangan harus dapat diinterpretasikan oleh para pihak yang memiliki kepentingan (interested party) dengan persepsi yang sama. Untuk itu perlu adanya suatu standar akuntansi yang mengatur penyajian laporan keuangan suatu perusahaan.

Oleh karena itu Ikatan Akuntan Indonesia (IAI) menerbitkan SAK ETAP pada tanggal 17 Juli 2009 dan berlaku secara efektif untuk penyusunan laporan keuangan yang dimulai pada atau setelah 1 Januari 2011. SAK ETAP diperuntukan bagi entitas yang tidak memiliki akuntabilitas publik segnifikan dan menerbitkan laporan keuangan untuk tujuan umum bagi pengguna eksternal.

PT. Fortuna Inti Alam merupakan perusahaan yang tidak memiliki akuntabilitas publik segnifikan dan menerbitkan laporan keuangan untuk tujuan umum (general purpose financial statement) bagi pengguna eksternal. Ciri tersebut termasuk dalam entitas yang menggunakan standar akuntansi keuangan entitas tanpa akuntabilitas publik (SAK ETAP). Dengan adanya SAK ETAP, PT. Fortuna Inti Alam akan mendapatkan kemudahan dalam menyusun laporan keuangannya.

Berdasarkan uraian diatas, maka dapat disimpulkan bahwa setiap perusahaan harus memiliki laporan keuangan yang akurat dan berdasarkan peraturan yang berlaku. Untuk perusahaan kecil menengah telah taerdapat SAK ETAP yang mempermudah penyusunan laporan keuangannya. Oleh karena itu, penulis terdorong untuk melakukan penelitian dengan judul "Analisis Penyajian Laporan Keuangan Berdasarkan Penerapan Standar Akuntansi Keuangan Entitas Tanpa Akuntabilitas Publik (SAK ETAP) Pada PT. Fortuna Inti Alam".

\section{TINJAUAN PUSTAKA}

\subsection{Konsep Akuntansi}

Dalam dunia perusahaan ilmu akuntansi sangat diperlukan untuk mengelola perusahaannya, agar dapat diketahui kemajuan dan kemunduran dari usaha sebuah perusahaan tersebut. Dengan adanya akuntansi perusahaan dapat mengontrol laju perkembangan perusahaannya.

Pengertian akuntansi menurut Pura (2013:4), adalah seperangkat pengetahuan yang mempelajari perekayasaan dalam penyediaan jasa, yang berupa informasi keuangan dari suatu unit organisasi dan cara penyampaian (pelaporan) informasi tersebut kepada pihak yang berkepentingan untuk dijadikan dasar pengambilan keputusan ekonomi. Sedangkan menurut Bahri (2016:2), menyatakan bahwa: "Akuntansi adalah seni pencatatan, penggolongan, pengikhtisaran, dan pelaporan atas suatu transaksi dengan cara sedemikian rupa, sistematis dari segi isi, dan berdasarkan standar yang diakui umum". 
Sementara itu, Soetjipto (2014:1) mendefinisikan akuntansi (accounting) adalah proses tiga aktivitas: identifikasi, pencatatan, dan komunikasi (identifying, recording, and communicating) peristiwa ekonomi sebuah organisasi (bisnis dan non bisnis) bagi pengguna informasi.

Berdasarkan beberapa pendapat diatas, dapat disimpulkan bahwa akuntansi adalah suatu aktivitas yang menyediakan sistem informasi mulai dari mengidentifikasi, mencatat, sampai menghasilkan laporan yang bersifat keuangan. Segala aktivitas dan laporan yang bersifat keuangan tersebut akan dilaporkan kepada pihak-pihak yang berkepentingan mengenai aktivitas ekonomi dan kondisi perusahaan.

\subsection{Laporan Keuangan}

Menurut Kasmir (2012:7), laporan keuangan adalah laporan yang menunjukkan kondisi keuangan perusahaan pada saat ini atau dalam suatu periode tertentu. Sedangkan menurut Priyati (2013:5), laporan keuangan adalah hasil akhir dari suatu proses pencatatan, pengelolaan, dan pemeriksaan dari transaksi financial dalam suatu badan usaha yang dirancang untuk pembuatan keputusan baik dalam maupun luar perusahaan mengenai posisi keuangan dan hasil usaha perusahaan.

\subsection{Tujuan Laporan Keuangan}

Secara umum laporan keuangan dibuat dengan tujuan untuk menyampaikan informasi tentang kondisi keuangan perusahaan pada suatu saat tertentu kepada para pemangku kepentingan (Samryn, 2014:33). Sedangkan menurut Pontoh (2013:24), mendefinisikan bahwa tujuan laporan keuangan adalah menunjukkan apa yang telah dilakukan manajemen (stewardship), atau pertanggungjawaban manajemen atas sumberdaya yang dipercayakan kepadanya.

Sedangkan menurut IAI dalam SAK ETAP (2009:2), tujuan laporan keuangan adalah menyediakan informasi posisi keuangan, kinerja keuangan, dan laporan arus kas suatu entitas yang bermanfaat bagi sejumlah besar pengguna dalam pengambilan keputusan ekonomi oleh siapapun yang tidak dalam posisi dapat meminta laporan keuangan khusus untuk memenuhi kebutuhan informasi tertentu. Dalam memenuhi tujuannya, laporan keuangan juga menunjukkan apa yang telah dilakukan manajemen (stewardship) atau pertanggungjawaban manajemen atas sumber daya yang dipercayakan kepadanya.

\subsection{Standar Akuntansi Keuangan Entitas Tanpa Akuntabilitas Publik (SAK ETAP)}

Pada bulan Juli 2009, Dewan Standar Akuntansi Internasional (International Accounting Standards Board / IASB) menerbitkan Standar Pelaporan Keuangan Internasional (IFRS) untuk usaha kecil dan menengah (small and medium entities / SMEs) yang menjadi efektif segera setelah penerbitannya. Standar Pelaporan (SAK ETAP) (IFRS untuk usaha kecil dan menengah) mempunyai suatu naskah sederhana dan berisi beberapa pengungkapan yang sunstansial dibandingkan dengan Standar Pelaporan Keuangan Internasional yang lengkap. Sandar tersebut juga menyediakan suatu kerangka akuntansi untuk entitas yang tidak memiliki ukuran atau sumber daya untuk mengadopsi Standar Pelaporan Keuangan Internasional keseluruhan. Dibandingkan dengan Standar Pelaporan Keuangan Internasional keseluruhan, pilihan kebijakan akuntansi, prinsip pengakuan dan prinsip pengukuran untuk aset, liabilitas, pendapatan, dan beban telah disederhanakan pada banyak bagian didalam standar ini (Ankarath, 2015:521).

Standar Akuntansi Keuangan Entitas Tanpa Akuntabilitas Publik merupakan standar akuntansi keuangan yang diperuntukan bagi entitas tanpa akuntabilitas publik. SAK ETAP hadir sebagai jawaban akan kebutuhan standar akuntansi keuangan yang dapat diterapkan dalam suatu perusahaan guna meningkatkan kualitas laporan keuangan.

IAI dalam SAK ETAP (2009:1) menyatakan bahwa entitas yang diijinkan menerapkan SAK ETAP pada laporan keuangannya adalah entitas yang:

1. Tidak memiliki akuntabilitas public signifikan 
2. Menerbitkan laporan keuangan untuk tujuan umum (general purpose financial statement)

Entitas yang memiliki akuntabilitas publik signifkan dapat menggunakan SAK ETAP jika otoritas berwenang membuat regulasi yang mengizinkan penggunaan SAK ETAP. Pada umumnya, entitas tanpa akuntabilitas publik adalah UMKM, oleh karena itu pengguna ETAP akan banyak terdiri dari entitas dengan kategori UMKM. Penerbitan PSAK ETAP oleh Dirjen Standar Akuntansi Keuangan (DSAK) Ikatan Akuntan Indonesia (IAI) ini adalah sebagai alternatif PSAK yang boleh diterapkan oleh entitas di Indonesia, sebagai bentuk PSAK yang lebih sederhana dibandingkan dengan PSAK Umum yang lebih rumit.

\subsection{Penyajian Laporan Keuangan}

\section{A. Kepatuhan Terhadap SAK ETAP}

Entitas yang laporan keuangannya mematuhi SAK ETAP harus membuat suatu pernyataan eksplisit dan secara penuh (explicit and unreserved statement) atas kepatuhan tersebut dalam catatan atas laporan keuangan. Laporan keuangan tidak boleh menyatakan mematuhi SAK ETAP kecuali jika mematuhi semua persyaratan dalam SAK ETAP.

\section{B. Frekuensi Pelaporan}

Entitas menyajikan secara lengkap laporan keuangan (termasuk informasi komparatif) minimum satu tahun sekali. Ketika akhir periode pelaporan entitas berubah dan laporan keuangan tahunan telah disajikan untuk periode yang lebih panjang atau lebih pendek dari satu tahun, maka entitas mengungkapkan:

a) fakta tersebut;

b) alasan penggunaan untuk periode lebih panjang atau lebih pendek; dan

c) fakta bahwa jumlah komparatif untuk laporan laba rugi, laporan perubahan ekuitas, laporan laba rugi dan saldo laba, laporan arus kas, dan catatan atas laporan keuangan yang terkait adalah tidak dapat seluruhnya diperbandingkan.

\subsection{Laporan Keuangan SAK ETAP Lengkap}

Laporan keuangan entitas meliputi:

a) Neraca;

b) Laporan laba rugi;

c) Laporan perubahan ekuitas yang juga menunjukkan:

1. seluruh perubahan dalam ekuitas, atau

2. perubahan ekuitas selain perubahan yang timbul dari transaksi dengan pemilik dalam kapasitasnya sebagai pemilik;

d) Laporan arus kas; dan

e) Catatan atas laporan keuangan yang berisi ringkasan kebijakan akuntansi yang signifikan dan informasi penjelasan lainnya.

\section{METODE PENELITIAN}

\subsection{Jenis dan sumber data}

Dalam penelitian ini, peneliti menggunakan jenis data kualitatif berupa profil perusahaan dan uraian mengenai laporan keuangan perusahaan (dalam hal ini format neraca dan laporan laba rugi). Dan menggunakan sumber data primer yaitu data yang dikumpulkan langsung dari objek penelitian (PT. Fortuna Inti Alam). Sedangkan, data sekunder diperoleh dari literatur- literatur, buku- buku yang bersangkutan dengan judul penelitian, dan penelitian- penelitian terdahulu.

\subsection{Teknik Pengumpulan Data}

Dalam penelitian ini, teknik pengumpulan data yang digunakan adalah wawancara dengan pihak terkait untuk memperoleh informasi mengenai data perusahaan dan dokumentasi berupa profil perusahaan dan format neraca dan laporan laba rugi tahun 2016. 


\section{3. $\quad$ Metode analisis}

Metode analisis yang digunakan dalam penelitian ini adalah sebagai berikut:

1. Deskriptif

Metode dimana peneliti mengumpulkan, menjelaskan, serta menganalisis data sehingga memberikan keterangan yang lengkap bagi masalah yang dihadapi. Data yang dimaksud berupa profil perusahaan, format neraca dan laporan laba rugi periode tahun 2016, dan data hasil wawancara bersama pihak terkait yaitu Ibu Selvie Lalawi.

2. Komparatif

Metode analisis yang dilakukan dengan membandingkan teori-teori dan standar yang berlaku yakni Standar Akuntansi Keuangan Entitas Tanpa Akuntabilitas Publik dengan praktik yang terjadi pada entitas, dalam hal ini laporan keuangan PT. Fortuna Inti Alam. Kemudian mengambil kesimpulan dari hasil perbandingan tersebut.

\section{HASIL ANALISIS DAN PEMBAHASAN}

\subsection{Hasil analisis}

Dari hasil wawancara yang dilakukan bersama Ibu Selvie Lalawi, SE, Ak selaku Finance Manager PT. Fortuna Inti Alam mengenai Standar Akuntansi Keuangan Entitas Tanpa Akuntabilitas Publik (SAK ETAP) bahwa PT. Fortuna Inti Alam telah menerapkan Standar Akuntansi Keuangan Entitas Tanpa Akuntabilitas Publik dalam laporan keuangannya meskipun belum sepenuhnya.

\section{Kelengkapan}

Laporan keuangan PT. Fortuna Inti Alam terdiri atas Neraca dan Laporan Laba Rugi. Maka dapat diketahui bahwa perusahaan ini belum memenuhi urgensi laporan keuangan secara lengkap menurut SAK ETAP, seperti: Laporan Perubahan Ekuitas, Laporan Arus Kas, dan Catatan Atas Laporan Keuangan.

\section{Frekuensi Pelaporan}

Frekuensi pelaporan PT. Fortuna Inti Alam untuk penyajian laporan keuangan mengacu pada siklus operasi normal yaitu setiap satu tahun, mulai 1 Januari s/d 31 Desember. Hal tersebut sesuai dengan yang disyaratkan SAK ETAP.

\section{Identifikasi Laporan Keuangan}

SAK ETAP mengatur identifikasi laporan keuangan untuk dapat membedakan laporan keuangan satu dengan yang lainnya, setiap komponen laporan keuangan perlu mencantumkan informasi di setiap laporannya. Berikut informasi yang harus disajikan:

a. Nama entitas pelapor dan perubahan dalam nama tersebut sejak laporan periode berakhir;

b. Tanggal atau periode yang dicakup oleh laporan keuangan, nama yang lebuh tepat bagi setiap komponen lapora keuangan;

c. Mata uang pelaporan;

d. Pembulatan angka yang digunakan dalam penyajian laporan keuangan.

Identifikasi laporan keuangan PT. Fortuna Inti Alam yang dilihat berdasarkan penyajian Neraca dan Laporan Laba Rugi, perusahaan telah mencantumkan nama entitas pelapor, tanggal atau periode laporan keuangan, dan mata uang pelapor.

\section{Neraca}

SAK ETAP tidak menentukan format atau urutan terhadap pos-pos yang disajikan. Namun hanya menyediakan daftar pos-pos yang berbeda baik sifat atau fungsinya untuk menjamin penyajian yang terpisah dalam Neraca.

Format Neraca yang dilakukan oleh PT. Fortuna Inti Alam menyajikan informasi mencakup pos-pos aktiva lancar, aktiva tetap, aktiva lain-lain, kewajiban jangka pendek, kewajiban jangka panjang, dan ekuitas telah sesuai karena akun-akun atau pos-pos dalam Neraca telah disajikan secara terpisah berdasarkan sifatnya masing-masing pos. 


\section{Laporan Laba Rugi}

Laparan laba rugi melaporkan pendapatan dan beban PT. Fortuna Inti Alam dalam suatu periode. Dalam laporan laba rugi, pendapatan disajikan pertama kali, kemudian diikuti dengan beban, dan terakhir laba (rugi) bersih dihitung setelah pengurangan dari pajak penghasilan.

Dalam Laporan Laba Rugi PT. Fortuna Inti Alam biaya/beban dikumpulkan berdasarkan fungsinya yaitu pelaporan penjualan terpisah dari biaya lainnya, seperti biaya operasional, biaya administrasi dan umum, dan biaya lain-lain.

\subsection{Pembahasan}

Berikut ini adalah analisis pembahasan mengenai penyajian laporan keuangan PT. Fortuna Inti Alam yang ditinjau kepatuhannya terhadap SAK ETAP.

1. Kelengkapan

Dalam SAK ETAP ada 5 jenis laporan yang harus dimiliki oleh entitas sehingga laporan keuangan dapat dikatan lengkap. Berikut adalah daftar yang harus dimiliki:

Tabel 1. Checklist Kelengkapan Laporan Keuangan PT. Fortuna Inti Alam

\begin{tabular}{clc}
\hline No & \multicolumn{1}{c}{ Elemen Laporan Keuangan } & Ada/Tidak \\
\hline 1 & Neraca & $\sqrt{ }$ \\
\hline 2 & Laporan Laba Rugi & $\sqrt{ }$ \\
\hline & $\begin{array}{l}\text { Laporan Perubahan Ekuitas yang juga menunjukkan: } \\
\text { a. Seluruh perubahan dalam ekuitas, atau } \\
\text { b. Perubahan ekuitas selain perubahan dari transaksi dengan } \\
\text { pemilik dalam kapasitasnya sebagai pemilik }\end{array}$ & $\times$ \\
& $\begin{array}{l}\text { Laporan Arus Kas } \\
\text { akuntasi yang signifikan dan informasi penjelasan lainnya }\end{array}$ & $\times$ \\
\hline 4 &
\end{tabular}

Sumber: Data Olahan 2017

Tabel 1 menunjukkan bahwa PT. Fortuna Inti Alam hanya membuat 2 dari 5 jenis laporan yang disyaratkan SAK ETAP. Yaitu perusahaan hanya membuat Neraca dan Laporan Laba Rugi. Jadi dapat dilihat bahwa laporan keuangan yang disajikan perusahaan belum dinyatakan lengkap menurut SAK ETAP.

2. Frekuensi Pelaporan

SAK ETAP mensyaratkan penyajian laporan keuangan minimal satu tahun sekali. PT. Fortuna Inti Alam telah memenuhi aspek ini dalam penyajian laporan keuangannya. Perusahaan juga membuat laporan laba rugi setiap akhir bulan, dan neraca setiap enam bulan sekali.

\section{Identifikasi Laporan Keuangan}

Laporan keuangan PT. Fortuna Inti Alam telah mencantumkan nama entitas pelapor, tanggal atau periode laporan keuangan, dan mata uang pelaporan pada Neraca dan Laporan Laba Rugi. PT. Fortuna Inti Alam belum mencantumkan pembulatan angka yang digunakan dalam laporan keuangan. Namun hal ini tidak berpengaruh secara material pada laporan keuangan PT. Fortuna Inti Alam.

4. Neraca

Berikut merupakan perbandingan Neraca menurut SAK ETAP dan penyajian Neraca menurut PT. Fortuna Inti Alam: 
Tabel 2. Perbandingan Neraca menurut SAK ETAP dengan Neraca PT. Fortuna Inti Alam

\begin{tabular}{|c|c|c|c|c|c|}
\hline No. & $\begin{array}{c}\text { Item yang } \\
\text { Dibandingkan }\end{array}$ & Paragraf & SAK ETAP & PT. Fortuna Inti Alam & Ket. \\
\hline 1 & $\begin{array}{l}\text { Dasar } \\
\text { Pencatatan }\end{array}$ & $\begin{array}{l}\text { Paragraf } \\
2.33\end{array}$ & $\begin{array}{l}\text { Dasar pencatatan neraca } \\
\text { menggunakan dasar akrual. }\end{array}$ & $\begin{array}{l}\text { Dasar pencatatan neraca } \\
\text { menggunakan dasar } \\
\text { akrual. }\end{array}$ & Sesuai \\
\hline 2 & Aset & $\begin{array}{l}\text { Paragraf } \\
4.2\end{array}$ & $\begin{array}{l}\text { Aset minimal menyajikan } \\
\text { pos - pos berikut: } \\
\text { a. Kas dan Setara Kas } \\
\text { b. Piutang Usaha dan } \\
\text { Piutang Lainnya } \\
\text { c. Persediaan } \\
\text { d. Properti investasi } \\
\text { e. Aset tetap } \\
\text { f. Aset tidak berwujud }\end{array}$ & $\begin{array}{l}\text { Aset menyajikan pos - } \\
\text { pos : } \\
\text { a. Kas/Bank } \\
\text { b. Piutang dagang } \\
\text { c. Persediaan } \\
\text { d. Uang muka sewa } \\
\text { e. Uang muka asuransi } \\
\text { f. Aktiva tetap } \\
\text { g. Aktiva lain - lain }\end{array}$ & Sesuai \\
\hline 3 & Kewajiban & $\begin{array}{l}\text { Paragraf } \\
4.2\end{array}$ & $\begin{array}{l}\text { Kewajiban minimal } \\
\text { menyajikan pos }- \text { pos } \\
\text { berikut: } \\
\text { a. Utang Usaha dan } \\
\text { Utang Lainnya } \\
\text { b. Aset dan Kewajiban } \\
\text { Pajak } \\
\text { c. Kewajiban } \\
\text { Diestimasi }\end{array}$ & $\begin{array}{l}\text { Kewajiban } \\
\text { menyajikan pos - pos: } \\
\text { a. Hutang Supplier } \\
\text { b. Hutang Pajak } \\
\text { c. Hutang Karyawan } \\
\text { d. Kewajiban Lain - } \\
\text { lain }\end{array}$ & Sesuai \\
\hline 4 & Ekuitas & $\begin{array}{l}\text { Paragraf } \\
4.3\end{array}$ & $\begin{array}{l}\text { Entitas menyajikan pos, } \\
\text { judul dan sub jumlah } \\
\text { lainnya }\end{array}$ & $\begin{array}{l}\text { Ekuitas menyajikan } \\
\text { pos - pos: } \\
\text { a. Modal Saham } \\
\text { b. Laba Ditahan } \\
\text { c. Laba Periode } \\
\text { Berjalan }\end{array}$ & Sesuai \\
\hline 5 & $\begin{array}{l}\text { Klasifikasi } \\
\text { Aset dan } \\
\text { Kewajiban }\end{array}$ & $\begin{array}{l}\text { Paragraf } \\
4.5\end{array}$ & $\begin{array}{l}\text { Entitas harus menyajikan } \\
\text { aset lancar dan aset tidak } \\
\text { lancar, kewajiban jangka } \\
\text { pendek dan kewajiban } \\
\text { jangka panjang, sebagai } \\
\text { suatu klasifikasi terpisah } \\
\text { dalam neraca, kecuali } \\
\text { jika penyajian } \\
\text { berdasarkan likuiditas } \\
\text { memberikan informasi } \\
\text { yang andal dan lebih } \\
\text { relevan. }\end{array}$ & $\begin{array}{lr}\text { PT. Fortuna Inti Alam } \\
\text { menyajikan } & \text { aktiva } \\
\text { lancar, aktiva } & \text { tetap, } \\
\text { aktiva lain }- & \text { lain, } \\
\text { kewajiban } & \text { jangka } \\
\text { pendek, } & \text { kewajiban } \\
\text { jangka } & \text { panjang, } \\
\text { sebagai } & \text { suatu } \\
\text { klasifikasi } & \text { terpisah } \\
\text { dalam neraca. }\end{array}$ & Sesuai \\
\hline
\end{tabular}

Sumber: Data Olahan 2017

Tabel 2 menunjukkan bahwa dari setiap item yang dibandingkan, Neraca PT. Fotuna Inti Alam telah sesuai dengan SAK ETAP. 


\section{Laporan Laba Rugi}

Bentuk laporan laba rugi yang dibuat oleh PT. Fortuna Inti Alam berupa penjualan, biaya-biaya, dan pendapatan lain. Berikut perbandingan Laporan Laba Rugi menurut SAK ETAP dengan Laporan Laba Rugi PT. Fortuna Inti Alam:

Tabel 3. Perbandingan Laporan Laba Rugi menurut SAK ETAP dengan Laporan Laba Rugi PT. Fortuna Inti Alam

\begin{tabular}{|c|c|c|c|c|c|}
\hline No. & $\begin{array}{c}\text { Item yang } \\
\text { Dibandingkan }\end{array}$ & Paragraf & SAK ETAP & $\begin{array}{c}\text { PT. Fortuna Inti } \\
\text { Alam }\end{array}$ & Ket. \\
\hline 1 & $\begin{array}{l}\text { Informasi yang } \\
\text { disajikan }\end{array}$ & $\begin{array}{l}\text { Paragraf } \\
5.3\end{array}$ & $\begin{array}{l}\text { Laporan laba rugi } \\
\text { minimal menyajikan } \\
\text { pos - pos berikut: } \\
\text { a. Pendapatan } \\
\text { b. Beban keuangan } \\
\text { c. Bagian laba atau } \\
\text { rugi dari investasi } \\
\text { yang menggunakan } \\
\text { metode ekuitas } \\
\text { d. Beban pajak } \\
\text { e. Laba atau rugi neto }\end{array}$ & $\begin{array}{l}\text { Laporan laba rugi } \\
\text { menyajikan pos - } \\
\text { pos : } \\
\text { a. Penjualan } \\
\text { b. Biaya } \\
\text { operasional } \\
\text { c. Biaya } \\
\text { administrasi } \\
\text { dan umum } \\
\text { d. Beban pajak } \\
\text { e. Laba bersih }\end{array}$ & Sesuai \\
\hline 2 & $\begin{array}{l}\text { Informasi yang } \\
\text { disajikan }\end{array}$ & $\begin{array}{l}\text { Paragraf } \\
5.4\end{array}$ & $\begin{array}{l}\text { Entitas harus } \\
\text { menyajikan pos, judul } \\
\text { dan sub jumlah lainnya } \\
\text { pada laporan laba rugi } \\
\text { jika penyajian tersebut } \\
\text { relevan untuk } \\
\text { memahami kinerja } \\
\text { keuangan entitas. }\end{array}$ & $\begin{array}{l}\text { PT. Fortuna Inti } \\
\text { Alam menyajikan } \\
\text { pos pendapatan dan } \\
\text { biaya lain, terdiri } \\
\text { dari: } \\
\text { a. Pendapatan } \\
\quad \text { Lain } \\
\text { b. Biaya Lain }\end{array}$ & Sesuai \\
\hline
\end{tabular}

Sumber: Data Olahan 2017

Tabel 3 menunjukkan bahwa dari setiap item yang dibandingkan, Laporan Laba Rugi PT. Fotuna Inti Alam telah sesuai dengan SAK ETAP.

\section{KESIMPULAN DAN SARAN}

\subsection{Kesimpulan}

Dari hasil analisis penyajian laporan keuangan PT. Fortuna Inti Alam berdasarkan

SAK ETAP diperoleh kesimpulan bahwa:

1. PT. Fortuna Inti Alam telah menerapkan SAK ETAP dalam penyajian laporan keuangannya, namun belum sepenuhnya lengkap. SAK ETAP mensyaratkan laporan keuangan yang lengkap terdiri atas Neraca, Laporan Laba Rugi, Laporan Perubahan Ekuitas, Laporan Arus Kas, dan Catatan Atas Laporan Keuangan. Namun perusahaan hanya membuat Neraca dan Laporan Laba Rugi.

2. Frekuensi pelaporan PT. Fotuna Inti Alam mengacu pada siklus operasi normal yaitu setiap satu tahun. Hal tersebut sesuai dengan yang disyaratkan SAK ETAP.

3. Dalam identifikasi laporan keuangan PT. Fortuna Inti Alam telah mencantumkan nama entitas pelapor, tanggal atau periode laporan keuangan, dan mata uang pelaporan. PT. Fortuna Inti Alam belum mencantumkan pembalutan angka yang digunakan dalam penyajian laporan keuangan, namun hal ini tidak berpengaruh secara material pada penyajian laporan keuangan PT. Fortuna Inti Alam. 
4. Dalam penyajian Neraca PT. Fortuna Inti Alam telah mengatur pengelompokkan aset menurut likuiditasnya, dan kewajiban menurut jangka waktu penyelesaiannya. Jadi dalam hal ini Neraca PT. Fortuna Inti Alam telah sesuai dengan SAK ETAP.

5. Dalam Laporan Laba Rugi PT. Fortuna Inti Alam telah memasukkan semua pos penghasilan dan beban yang diakui dalam satu periode serta menyajikan pos, judul dan sub jumlah lainnya. Hal ini sesuai dengan yang disyaratkan SAK ETAP.

\subsection{Saran}

Berdasarkan penelitian yang telah dilakukan, berikut ini adalah saran yang diberikan oleh penulis:

1. PT. Fortuna Inti Alam sebaikanya membuat Laporan Perubahan Ekuitas, Laporan Arus Kas, dan Catatan Atas Laporan Keuangan agar laporan keuangan yang disajikan lebih lengkap, relevan, dan dapat diandalkan.

2. Perusahaan secara umum belum mengungkapkan kebijakan akuntansi signifikan pada catatan atas laporan keuangan, maka sebaiknya dibuat catatan atas laporan keuangan yang memuat tentang kebijakan akuntansi yang diterapkan oleh perusahaan.

\section{DAFTAR PUSTAKA}

Ankarath, Nandakumar. Metha, Kalpesh. Ghosh. Alkafaji, Yass. 2015. Memahami IFRS Standar Pelaporan Keuangan Internasional. PT. Indeks Permata Puri Media, Jakarta Barat.

Bahri, Syaiful. 2016. Pengantar Akuntansi Berdasarkan SAK ETAP dan IFRS. CV. Andi Offset (Penerbit Andi, Anggota IKAPI), Yogyakarta.

Budiarso, Novi. 2015. Evaluasi Penerapan SAK ETAP pada PT. Bank Perkreditan Rakyat Cipta Cemerlang Indonesia. Jurnal Ilmiah Fakultas Ekonomi dan Bisnis Universitas Sam Ratulangi, Manado.

Harahap, Sofyan Syafri. 2013. Analisis Kritis Atas Laporan Keuangan. Penerbit Rajawali Pers, Jakarta.

Ikatan Akuntan Indonesia (IAI). 2009. Standar Akuntansi Keuangan Entitas Tanpa Akuntabilitas Publik. Dewan Standar Akuntansi Keuangan, Jakarta.

Jumingan. 2014. Studi Kelayakan Bisnis. PT Bumi Aksara, Jakarta.

Kasmir. 2012. Analisis Laporan Keuangan. Penerbit Rajawali Pers, Jakarta.

Pontoh, Wisnton. 2013. Akuntansi: Konsep dan Aplikasi. Halaman Moeka, Jakarta.

Priyati. 2013. Pengantar Akuntansi. PT. Indeks, Jakarta Barat.

Pura, Rahman. 2013. Pengantar Akuntansi I - IFRS 1. Penerbit Erlangga, Jakarta.

Samryn, 2014. Pengantar Akuntansi: Mudah Membuat Jurnal Dengan Pendekatan Siklus Transaksi. Penerbit Rajawali Pers, Jakarta.

Senoaji, Aditya Rizqi. 2014. GAP Analysis Penerapan SAK ETAP pada Penyusunan Laporan UKM di kabupaten Kudus. Jurnal Ilmiah Mahasiswa FEB Universitas Diponegoro.

Soetjipto, Ken Subardiman. 2014. Akuntansi; Suatu Pengantar. Penerbit Graha Ilmu, Yogyakarta. 